\title{
Organic Solar Cells: From a Lab Curiosity to a Serious Photovoltaic Technology (Presentation Video)
}

\section{Karl Leo}

Karl Leo, "Organic Solar Cells: From a Lab Curiosity to a Serious Photovoltaic Technology (Presentation Video)," Proc. SPIE 9184, Organic Photovoltaics XV, 918402 (20 November 2014); doi: 10.1117/12.2067925

SPIE Event: SPIE Organic Photonics + Electronics, 2014, San Diego, California, United States 


\title{
Organic Solar Cells: From a Lab Curiosity to a Serious Photovoltaic Technology (Presentation Video)
}

Karl Leo, Technische Univ. Dresden (Germany) and King Abdullah Univ. of Science and Technology (Saudi Arabia)

\begin{abstract}
Carbon-based organic semiconductors have many potential advantages like easy large-area preparation on flexible substrates, large variety of materials, and low cost. Organic solar cells have recently achieved significant progress and have crossed the $10 \%$ efficiency mark. In this talk, I will present an overview over the key features of solid-state organic solar cells and recent developments in the field. One central research area is the design of the bulk heterojunction active layer, requiring a nanoscale phase separation and optimized morphology to achieve efficient operation. I will also discuss highly efficient tandem structures with optimized electrical and optical properties, having the potential for approx. $20 \%$.
\end{abstract}

View presentation video on SPIE's Digital Library: http://dx.doi.org/10.1117/12.2067925 